Sitt. 1983, 24, 136-142

\title{
Enzymes of collagen synthesis and type III procollagen aminopropeptide in the evaluation of D-penicillamine and medroxyprogesterone treatments of primary biliary cirrhosis
}

\author{
E-R SAVOLAINEN, T A MIETTINEN. P PIKKARAINEN. \\ M P SALASPURO. AND K I KIVIRIKKO*
}

From the Department of Medical Biochemistry, University of Oulu, Oulu, and Second Department of Medicine. University of Helsinki. Helsinki. Finland

SUMMARY Changes in serum immunoreactive prolyl hydroxylase protein (IRPH), galactosylhydroxylysyl glucosyltransferase activity (GGT) and the aminoterminal propeptide of type III procollagen [Pro(III)-N-P] were studied in 21 patients with primary biliary cirrhosis during a follow-up period of up to three years. The patients received either D-penicillamine $(600 \mathrm{mg} / \mathrm{day})$, medroxyprogesterone acetate $(5 \mathrm{mg} / \mathrm{day})$, or a placebo, or no treatment after the $D$ penicillamine or medroxyprogesterone medication, each period lasting from nine to 15 months. The individual serum IRPH, GGT, and Pro(III)-N-P concentrations exceeded the upper normal limit in most patients. No significant changes were found in any of these three serum markers during any of the five different periods. nor was there any evidence for a decrease in the raised prolyl 4-hydroxylase activity in the hepatic biopsy specimens in response to any of the treatments. Galactosylhydroxylysyl glucosyltransferase activity decreased significantly in these specimens during medroxyprogesterone therapy, but the interpretation of this, the only positive change, remains unclear. The data suggest that D-penicillamine or medroxyprogesterone therapy may have no favourable effect on the increased hepatic collagen formation involved in primary biliary cirrhosis.

Primary biliary cirrhosis is a progressive disease for which no satisfactory treatment is available. Controlled trials have shown that $\mathrm{D}$-penicillamine reduces the raised hepatic copper concentration. improves some liver function tests, normalises some immunological abnormalities, and improves the survival of the patients during prolonged treatment. ${ }^{1-6}$ Another therapeutic approach which has been reported to produce some beneficial responses involves the induction of microsomal hepatic enzymes with medroxyprogesterone. ${ }^{7}$

During recent years attempts have been made to develop assays for the evaluation of hepatic collagen

\footnotetext{
* Address for correspondence: Professor K I Kivirikko. Department of Medical Biochemistr!. Lniversit! of Oulu. SF-90220) Oulu 22. Finland Received for publication + May 1982
}

synthesis by studying serum samples. Two enzymes of collagen synthesis can be measured in serum as immunoreactive prolyl hydroxylase protein $^{8}$ (IRPH) and galactosylhydroxylysyl glucosyltransferase activity $^{y}$ (GGT). These serum enzymes are raised in patients with cirrhosis, acute hepatitis, hepatoma, and metastases of the liver, whereas they are usually within the normal limits in patients with fatty liver and extrahepatic cholestasis. ${ }^{1(-13}$ The two serum enzymes correlate significantly with the corresponding enzyme activity in the liver biopsy specimens, but less consistently with the liver function tests. ${ }^{10-12}$ It thus seems that serum IRPH and GGT may give useful information on actual hepatic collagen synthesis in the follow-up of liver diseases. Serum assays are also available for the amino-terminal propeptide of type III procollagen [Pro(III)-N-P] ${ }^{14}$ The procollagens are biosynthetic 
precursors of various collagen types and are converted to collagens by cleavage of the propeptides in the extracellular space. ${ }^{15}$ in High serum Pro(III)-N-P concentrations are found in several liver diseases. ${ }^{13} 14$

The aim of the present work was to study the therapeutic effect of D-penicillamine and medroxyprogesterone in primary biliary cirrhosis with special emphasis on hepatic collagen synthesis. IRPH, GGT, and Pro(III)-N-P were measured in serum, and prolyl hydroxylase activity (ActPH) and GGT in liver biopsy specimens.

\section{Methods}

\section{PATIENTS}

The studies were carried out on 20 female patients and one male with primary biliary cirrhosis, their ages ranging from 32 to 68 years (mean 54 years). In each case the diagnosis was based on the typical clinical, biochemical, and histological findings ${ }^{17}$ described earlier. ${ }^{18}$ Histologically, one patient had a florid duct lesion (stage I), six had ductular proliferation (stage II), nine exhibited scarring (stage III), and five had cirrhosis (stage IV). Three different treatments were provided: D-penicillamine (600 mg daily), medroxyprogesterone acetate $(5 \mathrm{mg}$ daily), or a placebo. In some patients the Dpenicillamine therapy was interrupted for one year followed either by medroxyprogesterone or the placebo. The different groups thus comprised six periods with D-penicillamine, 11 on medroxyprogesterone, nine on placebo, eight with no treatment after D-penicillamine, and nine with no treatment after medroxyprogesterone. Each period lasted from nine to 15 months. The purpose and design of the study were explained to the patients, and they participated voluntarily.

\section{LIVER BIOPSIES AND SERA}

The liver biopsies were performed during laparoscopy, and part of each specimen was used for diagnostic histological examination. The portion of the biopsy set aside for chemical analysis was rapidly frozen in liquid nitrogen and stored at $-70^{\circ} \mathrm{C}$ until assayed for total protein, ActPH, and GGT. The sera were stored at $-20^{\circ} \mathrm{C}$ until assayed for IRPH, GGT, and Pro(III)-N-P.

ASSAYS

Serum IRPH was determined with a direct radioimmunoassay based on the displacement of radioactively-labelled human prolyl hydroxylase ${ }^{19}$ from its antibody by non-labelled enzyme and the subsequent precipitation of the enzyme-antibody complex by a cellulose-bound second antibody. ${ }^{20}$
Serum GGT was assayed by measuring the amount of radioactive glucosylgalactosylhydroxylysine formed from UDP- $\left[{ }^{1+} \mathrm{C}\right]$ glucose in a gelatinised calf skin collagen substrate. ${ }^{21} 22$ One unit of GGT was defined as described earlier. ${ }^{23}$ Serum Pro(III)-N-P was determined using a radioimmunoassay kit (Behringwerke AG, Germany) based on the displacement of radioactively-labelled type III amino-propeptide and the subsequent precipitation of the peptide-antibody complex by a second antibody. ${ }^{14}$

The frozen liver biopsy specimens were homogenised in $0.5 \mathrm{ml}$ of an ice-cold solution of $0 \cdot 2 \mathrm{M} \mathrm{NaCl}, 0 \cdot 1 \mathrm{M}$ glycine, $50 \mu \mathrm{M}$ dithiothreitol, $0.1 \%(\mathrm{w} / \mathrm{v})$ Triton $\mathrm{X}-100,0.01 \%(\mathrm{w} / \mathrm{v})$ soy bean trypsin inhibitor, and $20 \mathrm{mM}$ Tris- $\mathrm{HCl}$ buffer, adjusted to $\mathrm{pH} 7.5$ at $4^{\circ} \mathrm{C}$, in a Teflon and glass homogeniser at about $1500 \mathrm{rev} / \mathrm{min}$ for $60 \mathrm{~s} .{ }^{17} \mathrm{An}$ aliquot of each homogenate was taken for the assay of total protein. ${ }^{24}$ The homogenates were then centrifuged at $15000 \times g$ for 30 minutes, and aliquots of the supernatants were taken for the enzyme assays. ActPH was determined by measuring the formation of radioactive 4hydroxyproline in a $\left[{ }^{14} \mathrm{C}\right]$ proline-labelled protocollagen substrate prepared in isolated chick embryo tendon cells, and the values are expressed as activity units. ${ }^{25}$ GGT was measured by the method of Myllylä et al. ${ }^{21} 23$ Standard hospital laboratory methods were used for those determinations not specified above.

The statistical significances between two means were calculated by Student's $t$ test and the correlations by linear regression analysis.

\section{REFERENCE VALUES}

Reference values for serum IRPH in 42 apparently healthy persons ranging in age from 14 to 61 years have been reported previously. ${ }^{1126} 27$ The mean IRPH is $1 \cdot 24 \pm 0 \cdot 16$ (SD) $\mathrm{mg} / \mathrm{l}$ and the upper normal limit $1.56 \mathrm{mg} / \mathrm{l}$ (mean $\pm 2 \mathrm{SD}) .{ }^{27}$ Reference values for serum GGT were available from the same subjects, ${ }^{12} 2627$ but additional determinations were carried out in 35 new ones (aged 20-52 years), the mean for the 77 controls being $0.43 \pm 0.07 \mathrm{U} / \mathrm{l}$ and the upper normal limit $0.57 \mathrm{U} / \mathrm{l}$. References values for serum Pro(III)-N-P were determined in the above 35 new. controls, the mean being $9 \cdot 81 \pm 1 \cdot 71$ $\mu \mathrm{g} / \mathrm{l}$, and the upper normal limit $13.2 \mu \mathrm{g} / \mathrm{l}$. Some control samples were re-assayed in each series together with the samples from the patients. Reference values for liver ActPH and GGT are not available for healthy subjects, but the following activities have been reported by us in a group of eight patients with fatty liver: ActPH $1 \cdot 13 \pm 0.35$ (SD) U/g liver protein and GGT $0 \cdot 65 \pm 0 \cdot 13 \mathrm{U} / \mathrm{g} .^{1112}$ 
Results

CHANGES IN SERUM IRPH, GGT, AND PRO(III)-N-P When treatment started the individual serum GGT and Pro(III)-N-P values were above the mean for the controls in all the patients, and the IRPH concentrations in all but one (Figs 1-3). Most of these values also exceeded the upper normal limit (mean $+2 \mathrm{SD}$ of the controls). No significant changes were found in any of these three serum markers after the treatment with either Dpenicillamine, medroxyprogesterone, or a placebo, there not being even any sign of a positive trend (Table). Similarly no significant changes were observed when the patients were receiving no medication after D-penicillamine or medroxyprogesterone. The individual serum IRPH, GGT, and Pro(III)-N-P values in most patients were relatively constant during the whole follow-up period, some continuing to show mildly raised concentrations while others had high values (Figs 1-3). No correlation was found between any of these three serum markers and the histological grading of the disease stage.

CHANGES IN LIVER ACtPH AND GGT

Liver ActPH was not altered significantly by treatment with medroxyprogesterone or the placebo, whereas liver GGT decreased significantly during medroxyprogesterone medication (Table). The effect of D-penicillamine treatment on these two liver enzymes could not be determined accurately because of the small number of samples, but it is significant that the activities at the end of this treatment were not significantly lower than at the end of any other period, and there was not even any trend towards a reduced activity (Table).

CORRELATION BETWEEN TESTS

A significant correlation was found between all three serum markers in the pooled group of patients (IRPH vs GGT, $\mathrm{p}<0 \cdot(00)$; GGT vs Pro(III)-N-P, $\mathrm{p}<0 \cdot 001$ : IRPH vs Pro(III)-N-P, $\mathrm{p}<0 \cdot(\mathbf{0 2 )}$. Both serum enzymes also correlated with the respective enzyme activity in the liver biopsy specimens (serum IRPH vs liver ActPH, $\mathrm{p}<() \cdot(05$; serum GGT vs liver GGT, $\mathrm{p}<0 \cdot(0)(0)$.

No clinical improvement was observed during any of the treatment periods, nor were there any significant changes in the liver function tests in any of the groups (details not shown). The three serum markers correlated significantly with serum aspartate aminotransferase (ASAT vs IRPH or GGT, $\mathrm{p}<() \cdot(0) 1$ : ASAT is Pro(III)-N-P, $\mathrm{p}<0 \cdot 01)$, and serum IRPH and GGT also correlated with alanine aminotransferase $(p<0 \cdot()() 1)$. No significant correlation was found between any of these three markers and serum alkaline phosphatase. A significant correlation was also found between liver GGT and ASAT $(\mathrm{p}<() \cdot() 2)$.

\section{Discussion}

The present and previous ${ }^{10-12}$ data indicate that serum IRPH and GGT are raised in a high percentage of patients with primary biliary cirrhosis.

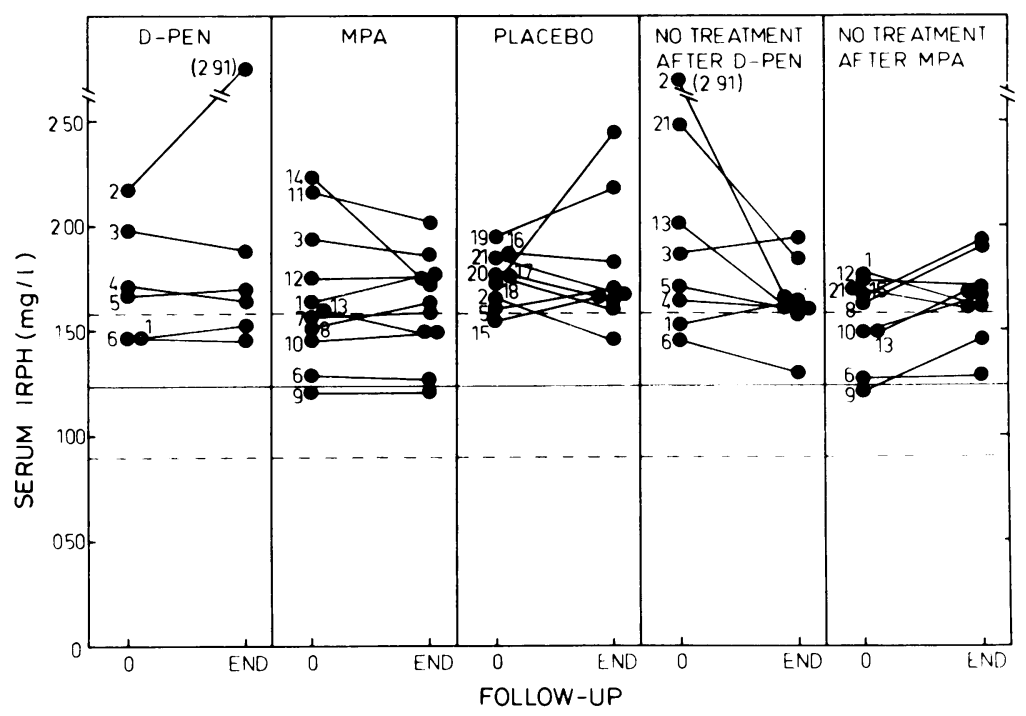

Fig. 1 Serum IRPH in patients with primary biliary cirrhosis receiving treatment with D-penicillamine (D)-pen), medroxyprogesterone acetate (MPA), or a placebo, or no treatment after D-penicillamine or medroxyprogesterone acetate. The values were determined at the beginning (0) and at the end of each period lasting from nine to 1.5 months. The horizontal solid and dashed line's indicate the mean and limits of the mean $\pm 2.5 \mathrm{~S})$ for the controls. 


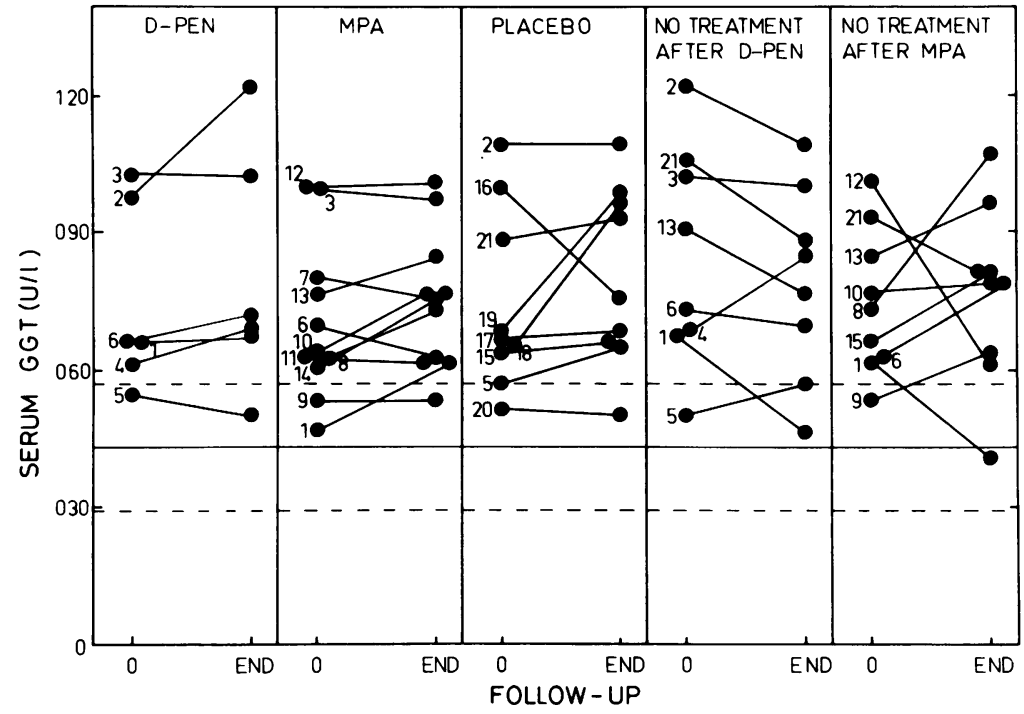

Fig. 2 Serum GGT in patients with primary biliary cirrhosis receiving treatment with $D$ penicillamine (D-pen), medroxyprogesterone acetate (MPA), or a placebo, or no treatment after D-penicillamine or medroxyprogesterone acetate. The values were determined at the beginning ( 0 ) and at the end of each period lasting from nine to 15 months. The horizontal solid and dashed lines indicate the mean and limits of the mean $\pm 2 S D$ for the controls.

The present data further indicate that serum Pro(III)-N-P is also increased in most patients with this disease. A significant correlation was found between these three tests, as previously reported for serum IRPH and GGT in several liver diseases, ${ }^{12}$ and for all three tests in patients with primary and secondary liver neoplasms. ${ }^{13}$

D-penicillamine may reduce the increased rate of collagen synthesis in primary biliary cirrhosis by its action on the immune system and on hepatic copper retention..$^{1-6}$ In the present study, however, the drug was not seen to have any effect on any of the serum markers of collagen synthesis or on the respective enzyme activities in the hepatic biopsy specimens. D-penicillamine treatment may thus have no favourable effect on hepatic collagen formation in primary biliary cirrhosis. This drug may also influence a late step in collagen biosynthesis, that of cross-link formation. ${ }^{28}$ Inhibition of this event would not be detected by the present assays. It

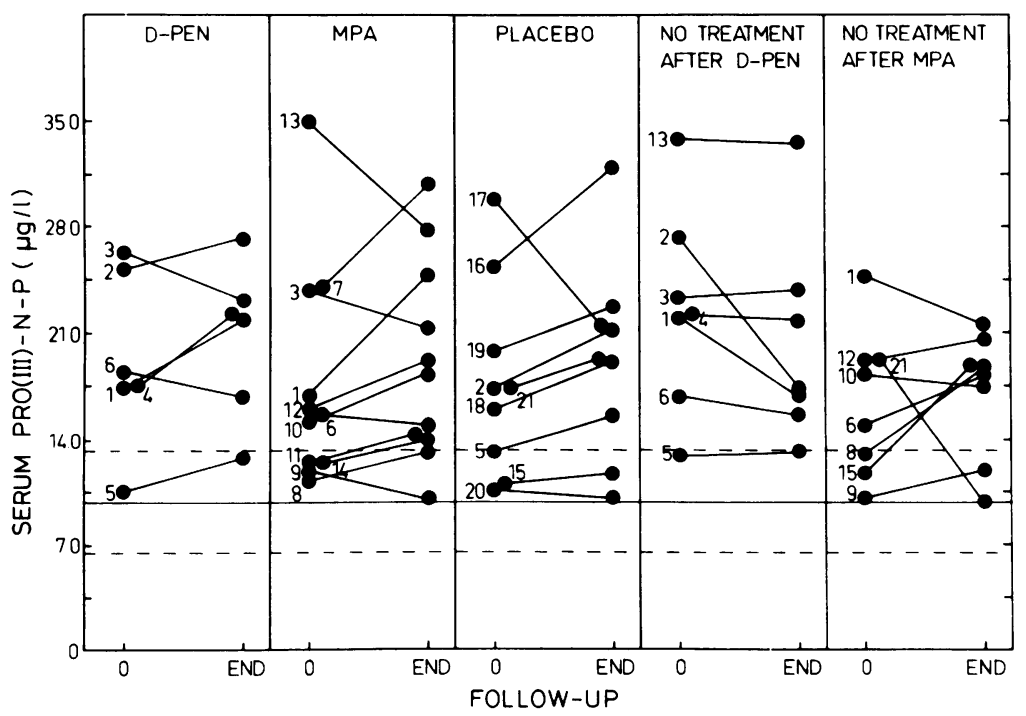

Fig. 3 Serum Pro(III)-N-P in patients with primary biliary cirrhosis receiving treatment with D-penicillamine (D-pen), medroxyprogesterone acetate (MPA), or a placebo, or no treatment after D-penicillamine or medroxyprogesterone acetate. The values were determined at the beginning ( $(0)$ and at the end of each period lasting from nine to 15 months. The horizontal solid and dashed lines indicate the mean and limits of the mean $\pm 2 S D$ for the controls. 


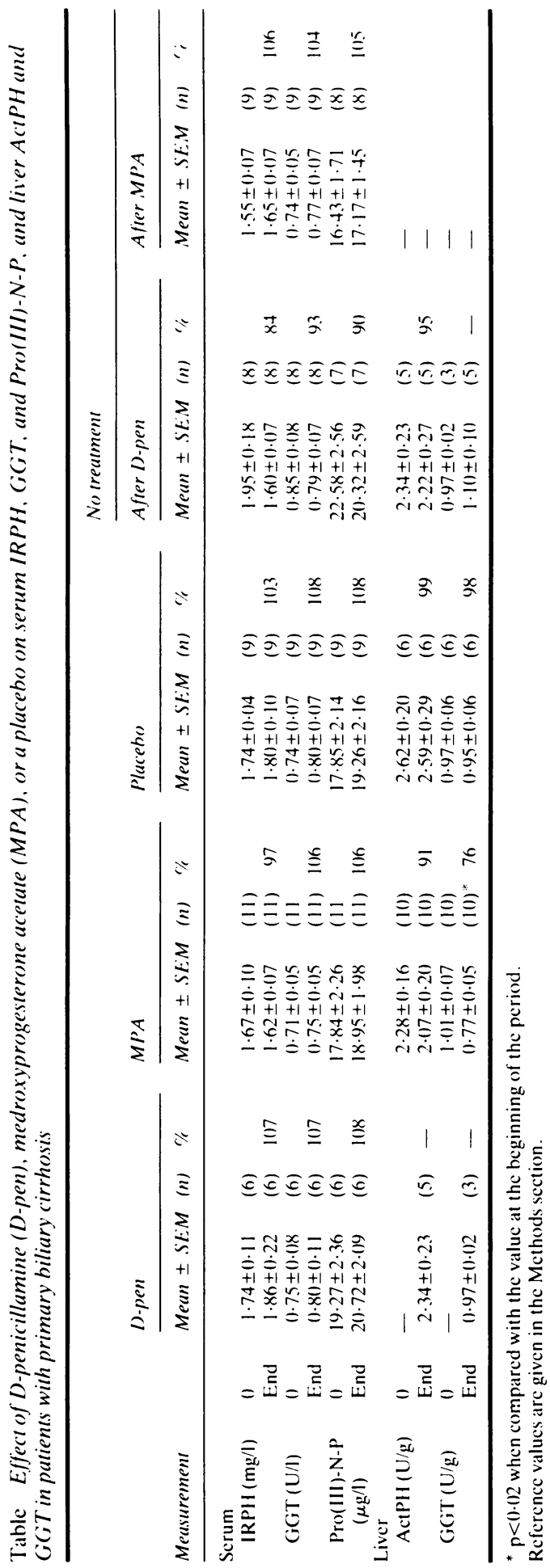


should be noted, however, that a much higher dosage of the drug is needed to achieve this action in animal experiments, ${ }^{2 x}$ suggesting that inhibition of collagen cross-linking is not a likely effect in the present case. In agreement with our data, it has been reported that, although D-penicillamine improved the survival of patients with primary biliary cirrhosis, the drug did not retard the histological evolution of the liver disease from the early prefibrotic stages to the late fibrotic and cirrhotic stages. ${ }^{5}$

Medroxyprogesterone treatment likewise had no effect on serum IRPH, GGT, or Pro(III)-N-P, or any of the liver function tests. A small decrease was found in liver GGT, but this was not associated with any significant change in liver ActPH, and thus the interpretation of this, the only positive change. remains unclear. The levels of ActPH generally increase and decrease with the rate of collagen synthesis, ${ }^{x}$ whereas levels of GGT do not always change in an identical manner to ActPH. ${ }^{89}{ }^{29}$ It thus seems probable that medroxyprogesterone medication may have no significant antifibrotic action in primary biliary cirrhosis, at least not with the dosage used.

This work was supported in part by grants from the Medical Research Council of the Academy of Finland. The Pro(III)-N-P kit was a gift from Behringwerke AG. The authors also gratefully acknowledge the expert technical assistance of Mrs Lea Torvela.

\section{References}

1 Jain S, Scheuer PJ, Samourian S, McGee JO'D. Sherlock S. A controlled trial of D-penicillamine therapy in primary biliary cirrhosis. Lancet 1977; 1: 831-4.

2 Fleming CR, Ludwig J, Dickson ER. Asymptomatic primary biliary cirrhosis. Presentation. histology, and results with D-penicillamine. Mayo Clin Proc 1978; 53: 587-93.

3 Dickson ER, Fleming CR, Ludwig J. Primary biliary cirrhosis. In: Popper H. Schaffner F, eds. Progress in liver diseases, vol VI. New York: Grune and Stratton. 1979: 487-502.

4 Epstein O. De Villiers D, Jain S, Potter BJ. Thomas HC, Sherlock S. Reducation of immune complexes and immunoglobulins induced by D-penicillamine in primary biliary cirrhosis. $N$ Engl $J$ Med 1979; 300: 274-8.

5 Epstein O, Jain S, Lee RG, Cook DG, Boss AM,
Scheuer PJ. Sherlock S. D-penicillamine treatment improves survival in primary biliary cirrhosis. Lancet 1981: 1: 1275-7.

6 Salaspuro MP. Pikkarainen P. Sipponen P. Vuori E. Miettinen TA. Hepatic copper in primary biliary cirrhosis: biliary excretion and response to penicillamine treatment. Gut 1981; 22: 901-6.

7 Sotaniemi EA. Hynnynen T. Ahlqvist J. Ahokas JT. Puoskari U. Pelkonen I. Effects of medroxyprogesterone on the liver function and drug metabolism of patients with primary biliary cirrhosis and chronic active hepatitis. $J$ Med 1978; 9: 117-28.

8 Kivirikko KI. Myllylä R. The hydroxylation of prolyl and lysyl residues. In: Freedman RB. Hawkins HC. eds. The enzymology of post-translational modification of proteins. London: Academic Press. 198(): 53-1()4.

9 Kivirikko KI. Myllylä R. Collagen glycosyltransferases. Int Rev Connect Tiss Res 1979; 8: 23-72.

1) Tuderman L. Risteli J. Miettinen TA. Kivirikko KI. Serum immunoreactive prolyl hydroxylase in liver disease. Eur J Clin Invest 1977: 7: 537-41.

11 Kuutti-Savolainen E-R. Risteli J, Miettinen TA. Kivirikko KI. Collagen biosynthesis enzymes in serum and hepatic tissue in liver disease. I. Prolyl hydroxylase. Eur J Clin Invest 1979; 9: 89-95.

12 Kuutti-Savolainen E-R, Anttinen H, Miettinen TA, Kivirikko KI. Collagen biosynthesis enzymes in serum and hepatic tissue in liver disease. II. Galactosylhydroxylysyl glucosyltransferase. Eur J Clin Invest 1979: 9: 97-101.

13 Bolarin DM, Savolainen E-R, Kivirikko KI. Enzymes of collagen synthesis and type III procollagen aminopropeptide in serum from Nigerians with hepatocellular carcinoma and other malignant diseases. Int J Cancer 1982; 29: 401-5.

14 Rohde H. Vargas L. Hahn E. Kalbfleisch H. Bruguera M. Timpl R. Radioimmunoassay for type III procollagen peptide and its application to human liver disease. Eur J Clin Invest 1979; 9: 451-9.

15 Prockop DJ, Kivirikko KI, Tuderman L. Guzman NA. The biosynthesis of collagen and its disorders. $N$ Engl J Med 1979: 301: 13-23, 77-85.

16 Bornstein P. Sage H. Structurally distinct collagen types. Ann Rev Biochem 1980; 49: 957-1003.

17 Sherlock S. Scheuer PJ. The presentation and diagnosis of 100 patients with primary biliary cirrhosis. $N E n g / J$ Med 1973: 289: 674-8.

18 Salaspuro MP, Sipponen P. Ikkala E. Kolho L, Makkonen HM. Miettinen TA, Räsänen JA. Siurala M. Clinical correlations and significance of orcein positivity in chronic active hepatitis and primary biliary cirrhosis. Ann Clin Res 1976; 8: 206-15.

19 Kuutti E-R. Tuderman L, Kivirikko KI. Human prolyl hydroxylase. Purification, partial characterization and preparation of antiserum to the enzyme. Eur J Biochem 1975; 57: 181-8.

20 Tuderman L. Kuutti E-R, Kivirikko KI. Radioimmunoassay for human and chick prolyl hydroxylases. Eur J Biochem 1975; 60: 399-405.

21 Myllylä R. Risteli L, Kivirikko KI. Assay of collagengalactosyltransferase and collagen-glucosyltransferase activities and preliminary characterization of enzymic 
reactions with transferases from chick-embryo cartilage. Eur J Biochem 1975; 52: 401-10.

22 Anttinen $\mathrm{H}$. Collagen glucosyltransferase activity in human serum. Clin Chim Acta 1977; 77: 323-30.

23 Myllylä R, Risteli L, Kivirikko KI. Collagen glucosyltransferase. Partial purification and characterization of the enzyme from whole chick embryos and chickembryo cartilage. Eur J Biochem 1976; 61: 59-67.

24 Lowry OH. Rosebrough NJ. Farr AL. Randall RJ. Protein measurement with the Folin phenol reagent. $J$ Biol Chem 1951; 193: 265-75.

25 Kivirikko KI, Myllylä R. Posttranslational enzymes in the biosynthesis of collagen: intracellular enzymes. Meth Enzymol 1982; 82: 245-304.

26 Kuutti-Savolainen E-R. Enzymes of collagen biosynthesis in skin and serum in dermatological diseases. II. Serum enzymes. Clin Chim Acta 1979; 96: 53-8.

27 Savolainen E-R, Kero M. Pihlajaniemi T. Kivirikko KI. Deficiency of glactosylhydroxylysyl glucosyltransferase, an enzyme of collagen synthesis, in a family with dominant epidermolysis bullosa simplex. $N$ Engl J Med 1981; 304: 197-204.

28 Nimni ME. Mechanism of inhibition of collagen crosslinking by penicillamine. Proc $R$ Soc Med 1977; 70, suppl 3: 65-72.

29 Kivirikko KI. Myllylä R. Post-translational modifications. In: Jayson MJV, Weiss JB, eds. Collagen in health and disease. Edinburgh: Churchill Livingstone. (In press.) 